\title{
PERANCANGAN E-COMMERCE UNTUK MENINGKATKAN PENJUALAN PADA SPACE VAPOR STORE
}

\author{
Rifki Ramadhan ${ }^{1)}$, Ita Novita ${ }^{2)}$ \\ ${ }^{1}$ Sistem Informasi, Fakultas Teknologi Informasi, Universitas Budi Luhur \\ ${ }^{1,2} \mathrm{Jl}$. Raya Ciledug, Petukangan Utara, Kebayoran Lama, Jakarta Selatan 12260 \\ E-mail : rifki.ramadhan1996@gmail.com ${ }^{1)}$, ita.novita@budiluhur.ac.id ${ }^{2)}$
}

\begin{abstract}
Abstrak
Space Vapor Store merupakan sebuah toko yang menjual perbagai macam produk vape. Space Vapor Store adalah sebuah toko yang bergerak dalam bidang penjualan aneka peralatan vape dan liquid. Sistem yang ada di Space Vapor Store saat ini masih terdapat banyak data - data yang ada didalam proses pemesanan dan proses pembuatan laporan yang belum tersimpan dengan baik, serta belum bisa untuk mengontrol data yang ada dan belum mempurluas pemasarannya, sehingga pemasarannya pun menjadi terbatas dan belum dikenal secara luas. Berdasarkan masalah tersebut, pembuatan rancangan sistem berbasis online dengan konsep E-Commerce menggunakan PHP sebagai bahasa pemrograman sangat dibutuhkan untuk kepentingan toko dalam melakukan perdagangan. Metodologi penelitian yang digunakan adalah wawancara, analisa dokumen, obesevasi dan studi pustaka. Untuk metode pengembangan sistem yang digunakan adalah waterfall. Dengan menggunakan metode ini diharapkan Space Vapor Store dapat menyelesaikan sesuatu masalah yang ada, mempermudah dalam memberikan informasi produk yang dibutuhkan secara akurat dan tepat, serta dapat diakses oleh siapa saja baik pihak Space Vapor Store maupun customer. Kemudian dapat mempermudah dalam memberikan informasi transaksi yang dilakukan oleh customer dan pembuatan laporan yang dibutuhkan pemilik toko sehingga dapat mengambil kebijakan, dapat meningkatkan penjualan dan pendapatan serta pelayanan terhadap customer yang lama maupun customer baru.
\end{abstract}

Kata kunci: E-Commerce, Space Vapor Store, Penjualan Vape.

\section{PENDAHULUAN}

Seiring dengan perkembangan teknologi informasi yang berkembang semakin maju maka memerlukan teknologi informasi yang cepat dan akurat. Dalam hal ini, komputer memegang peranan penting sebagai alat bantu dalam pengelohan data dan mempermudah penjualan. Kemajuan teknologi informasi yang cepat dapat berpengaruh besar bagi kehidupan dunia bisnis karena dapat menunjang kinerja pekerjaan, menghemat biaya dan waktu, serta mendapatkan informasi mudah.

Penulis menyusun laporan penelitian dengan mengadakan riset di Space Vapor Store merupakan suatu toko yang bergerak dalam bidang penjualan. Pengelohan data pada Space Vapor Store belum terolah dengan baik, masih membutuhkan waktu cukup lama, memberikan informasi masih salah karena kesalahan yang mungkin dilakukan manusia.

Permaasalahan yang ada di Space Vapor Store dapat diatasi dengan menggunakan sistem informasi penjualan yang akan membantu proses pekerjaan tersebut menjadi lebih baik dari sebelumnya. Penerapaan sistem informasi penjualan akan memberikan laporan menjadi lebih mudah, cepat dan akurat sehingga dapat mengatasi kerangkapan data, karena sudah menggunakan database yang sebagai media penyimpanan dan membantu memberikan pemecahan masalah yang terjadi dalam proses pengolahan data penjualan Space Vapor Store.

\section{STUDI PUSTAKA}

2.1. Konsep Dasar Sistem Informasi

Menurut (Krismiaji, 2015:15): "Sistem informasi adalah cara-cara yang diorganisasi untuk mengumpulkan, memasukkan, dan mengolah serta menyimpan data, dan cara-cara yang diorganisasi untuk menyimpan, mengelola, mengendalikan, dan melaporkan informasi sedemikian rupa sehingga sebuah organisasi dapat mencapai tujuan yang telah ditetapkan”.[1]

\subsection{Teori Pendukung}

Menurut (Ahmad \& Hendrawan, 2013) "Electronic Commerce (E-Commerce) adalah penjualan atau pembelian barang dan jasa, antara perusahaan, rumah tangga, individu, pemerintah, dan masyarakat atau organisasi swasta lainnya, yang dilakukan melalui komputer pada media jaringan”. [2]

\subsection{Studi Literatur}

Dalam upaya mengembangkan dan menyempurnakan sistem ini perlu dilakukan studi literatur penerapan metode penelitian yang akan dilakukan sebagai berikut yaitu:

a. Penelitian yang sejenis dalam jurnal penilaian sebagai acuan penulisan penelitian ini Sutri Handayani (2018) dengan judul "Perancangan Sistem Informasi Penjualan Berbasis E- 
Commerce Studi Kasus Toko Kun Jakarta” diterbitkan oleh p-ISSN 2087-1716 e-ISSN 2548-7779 Vol.10 No.2.[3]

b. Penelitian yang sejenis dalam jurnal penilaian sebagai acuan penulisan penelitian ini Marhamah, Sarip Hidayatuloh, Ari Irawan (2016) dengan judul "Sistem E-Commerce B2C Pada PT.Harapan Sentosa Nusantara Jakarta Pusat” diterbitkan oleh p-ISSN 1979-0767.[4]

c. Penelitian yang sejenis dalam jurnal penilaian sebagai acuan penulisan penelitian ini Sri Handayani, Anofrizen, M.Jazman (2016) dengan judul "Sistem Informasi E-Commerce Untuk Jaringan Penjualan Sepeda Motor Bekas Kabupaten Kampar” diterbitkan oleh e-ISSN 2502-8995 ISSN 2460-8181.[5]

\section{METODE PENELITIAN}

\subsection{Kerangka Kerja Penelitian}

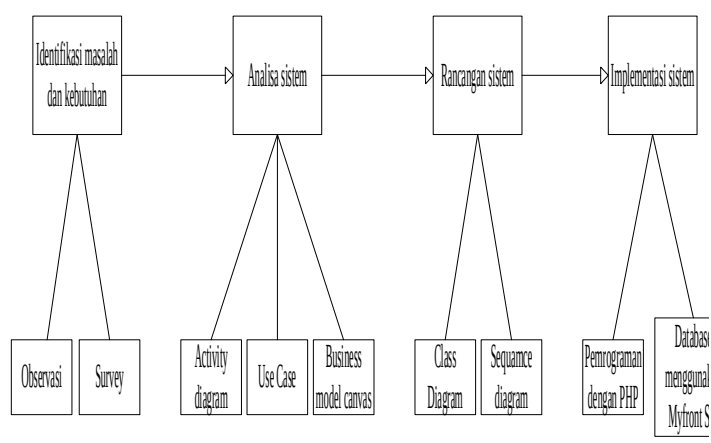

Gambar 1 ini merupakan kerangka kerja penelitian untuk pendekatan dan menjelaskan sistem.

\subsection{Metode Pengumpulan Data}

Untuk menyelesaikan masalah pada Space vapor store, maka dari itu penulis melakukan metode pengumpulan data, diantaranya sebagai berikut ini :
a. Observasi
b. Wawancara
c. Survei
d. Arsip

\section{ANALISIS DAN PEMBAHASAN 4.1. BUSINESS MODEL CANVAS (BMC)}

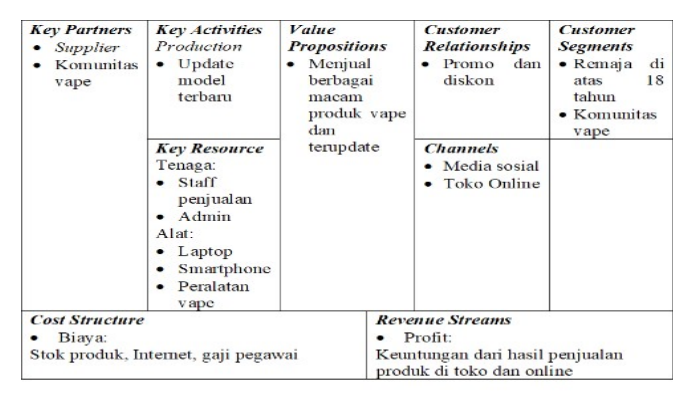

Gambar 2. Business Model Canvas

Pada gambar 2 menjelaskan tentang BusinessModel Canvas.

a. KEY PARTNERS

Key Partners Space Vapor Store supplier dan komunitas vape.

b. KEY ACTIVITY

Key activity pada Space Vapor Store adalah melakukan update model vape terbaru.

c. VALUE PROPOSITION

Space Vapor Store adalah toko yang bergerak dibidang penjualan vape. Space Vapor Store menjual berbagai macam produk vape dan terupdate.

d. CUSTOMER RELATIONSHIP

Customer relationship Space Vapor Store adalah memberikan promo dan diskon.

e. CUSTOMER SEGMENTS

Customer segments pada Space Vapor Store sebagai berikut:

1) Kalangan remaja yang umurnya 18 tahun keatas.

2) Komunitas pecinta vape.

f. KEY RESOURCES

Key resources pada Space Vapor Store sebagai berikut:

1) Tenaga yang meliputi: staff penjualan dan admin.

2) Alat yang meliputi: laptop, smartphone dan peralatan vape.

\section{g. CHANNEL}

Channel Space Vapor Store yaitu menggunakan sosial media dan toko online untuk mempopulerkan Space Vapor Store.

h. COST STRUCTURE

Cost structure pada Space Vapor Store yaitu meliputi biaya stok produk, gaji pegawai dan internet.

i. REVENUE STREAM

Revenue stream dari Space Vapor Store yaitu asset sale dimana pemasukan dapat dari penjualan produk vape yang dilakukan di toko dan penjualan online pada Space Vapor Store. 


\subsection{Proses Bisnis Usulan}

Proses bisnis usulan digambarkan menggunakan Activity Diagram sebagai berikut

1. Proses Penjualan

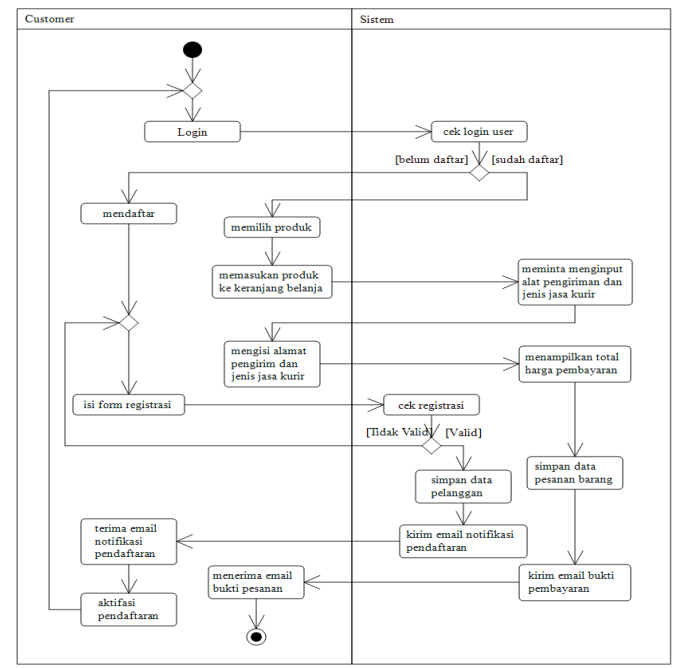

Gambar 3. Activity Diagram Penjualan

Proses penjualan dijelaskan pada gambar 3.

2. Proses Pembayaran

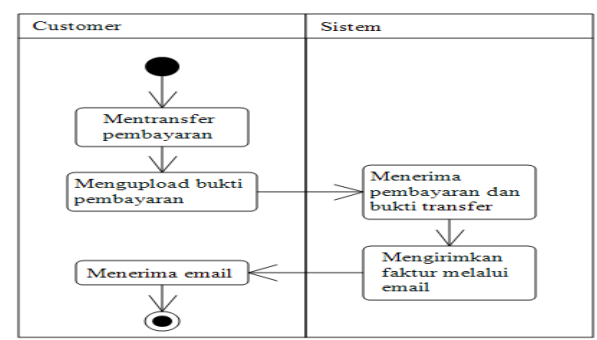

Gambar 4. Activity Diagram Pembayaran

Proses pembayaran dijelaskan pada gambar 4 .

3. Proses Laporan

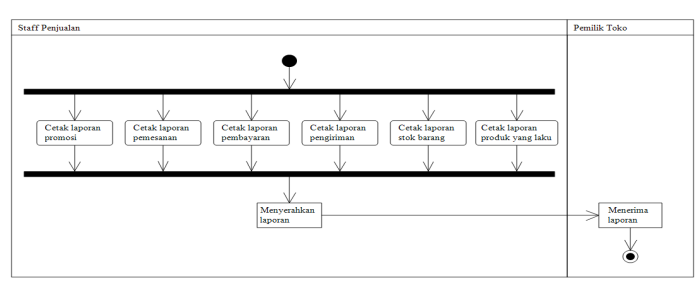

Gambar 5. Activity Diagram Konfirmas Pembayaran

Proses laporan dijelaskan pada gambar 5.

\subsection{Aturan Bisnis}

Adapun aturan bisnis dalan Space Vapor Store yaitu berikut ini :

a. Proses pembayaran paling lambat $1 \times 24$ jam, apabila customer tidak melakukan pembayaran pada waktu yang sudah ditentukan maka Space Vapor Store akan membatalkan pesanan.

b. Space Vapor Store tidak menerima retur.

\subsection{Use Case Diagram}

Dari masalah yang ditemukan oleh penulis. Penulis akan mencari kebutuhan sebagai user yang nantinya menjalankan sistem tersebut. Di gambarkan dengan use case diagram sebagai berikut ini

1. Use Case Diagram Master

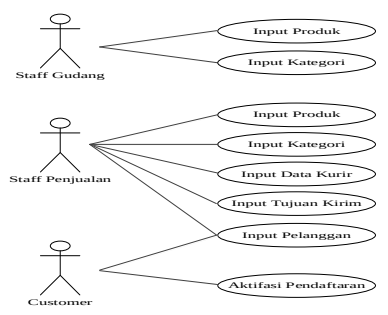

Proses use case diagram master dijelaskan ada aktor yaitu staff penjualan dan customer dan ada use case yaitu input produk, input kategori, input data kuriri, input tujuan kirim, input pelanggan dan aktifasi pendaftaran pada gambar 6.

2. Use Case Diagram Tansaksi
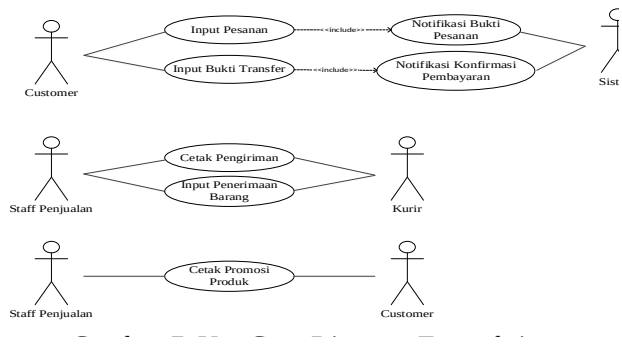

Proses use case diagram transaksi dijelaskan ada aktor yaitu staff penjualan customer sistem dan kurir dan ada use case yaitu input pesanan, input buktu transfer, notifikasi bukti pesanan, notifikasi konfirmasi pembayaran, cetak pengiriman, input pengiriman barang, cetak promosi produk pada gambar 7.

3. Use Case Diagram Laporan 


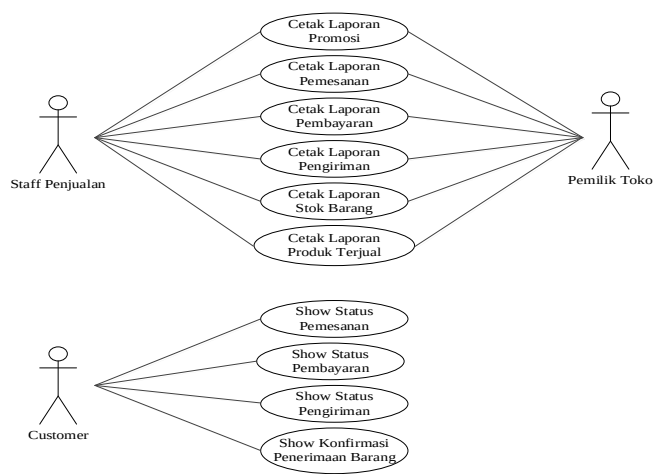

Famhar 8 I Iso Caso Dianram Iannran

Proses use case diagram master dijelaskan ada aktor yaitu staff penjualan, pemilik toko dan customer dan ada use case yaitu cetak laporan promosi pada gambar 8 .

\subsection{Basis Data}

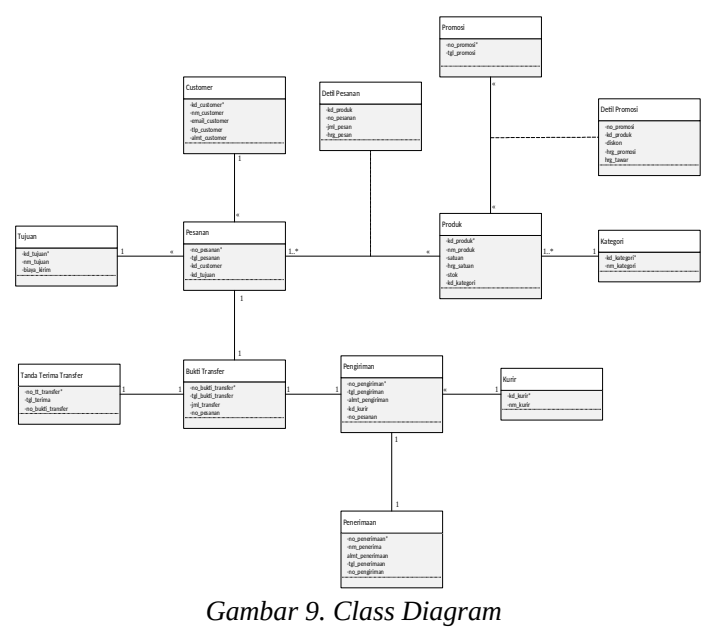

Adapun class diagram yang dibuat penulis pada gambar 9 .

\subsection{Struktur Tampilan (Menu)}

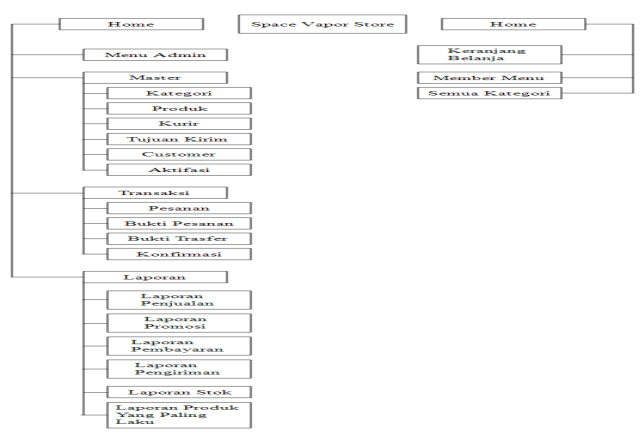

Gambar 10. Struktur Tampilan (Menu)
Adapun struktur tampilan yang dibuat penulis dijelaskan pada gambar 10 .

\subsection{Rancangan Layar}

1) Rancangan Layar Dashbord

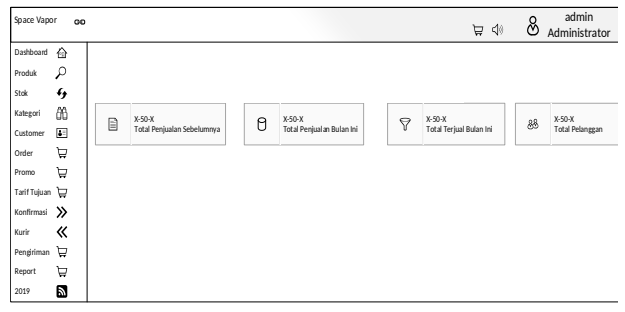

Tampilan dashboard digunakan oleh admin untuk halaman utama pada gambar 11.

2) Rancangan Layar Produk
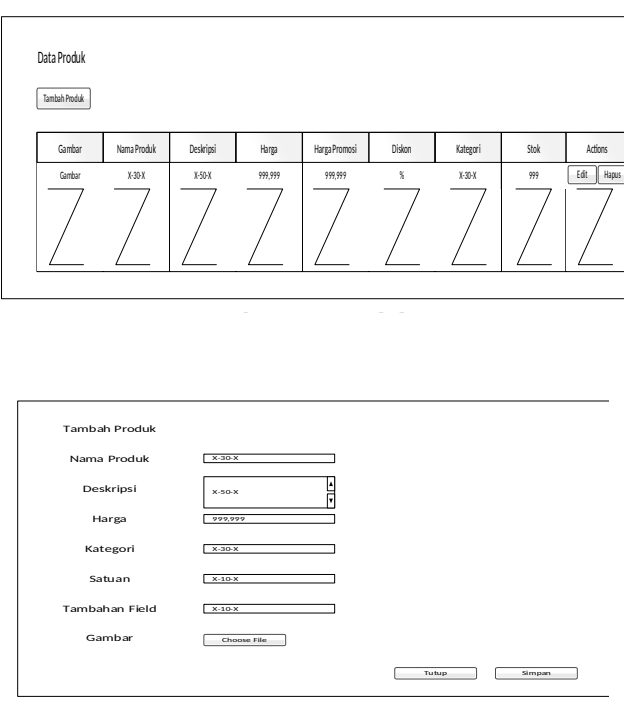

Tampilan produk digunakan oleh admin untuk menambahkan produk pada gambar 12 dan 13.

3) Rancangan Layar Order

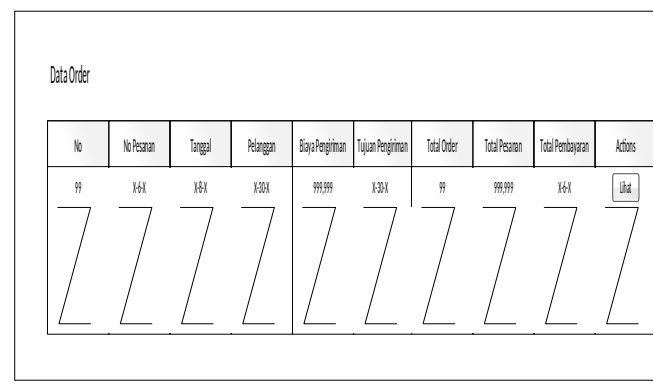

Tampilan order digunakan oleh admin untuk data orderan pada gambar 14.

4) Rancangan Layar Laporan Stok Produk 


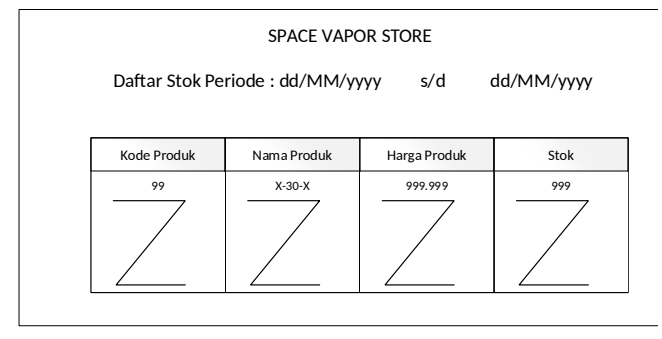

Gambar 15. Laporan Stok Produk

Tampilan laporan stok produk digunakan oleh admin untuk data orderan pada gambar 15.

\section{KESIMPULAN}

1. Dengan sistem yang ada saat ini, staff dengan mudah memasarkan stok yang lama karena sudah mempunyai website.

2. Dengan sistem yang ada saat ini, staff dapat mengetahui kapan stok kosongnya dengan mengecek di website dengan ketersediaan stoknya sisa berapa melalui fitur stok barang.

3. Dengan sistem yang ada saat ini, pelanggan dengan mudah mengetahui promo yang ada dengan mengecek di website melalui fitur hot promo.

4. Dengan sistem yang ada saat ini, pelanggan dapat memesan barang yang diinginkan dengan mudah melalui website $e$ commerce.

Dalam rancangan e-commerce yang diusulkan ini, penulis berharap agar rancangan yang telah dibuat tersebut dapat bermanfaat dengan baik, bagi kemajuan dan perkembangan toko. Untuk itu penulis mengusulkan beberapa saran, diantaranya:

a. Informasi adalah hal terpenting dalam suatu perusahaan, oleh karena itu perkembangan dan kebutuhan baru haruslah dicatat dengan baik. Sistem ini dirancang hanya untuk memaksimalkan beberapa kebutuhan yang ada saat ini dan saat yang akan datang, maka suatu saat sistem ini akan mempunyai kebutuhan baru yang diharuskan sistem ini untuk di update.

b. Untuk menghindari beberapa kesalahan yang mungkin akan timbul pada sistem ini, perlu dilakukan perawatan (maintenance).

c. Diharapkan pihak yang akan menggunakan sistem ini, terutama para karyawan Space Vapor Store mendapatkan sedikit pelatihan cara kerja kesuluruhan sistem.

d. Diperlukan back-up data secara bertahap terhadap data-data penting untuk mengantisipasi keadaan hilangnya data.
Dengan demikian kesimpulan dan saran ini. Semoga sistem e-commerce ini dapat meningkatkan penjualan di Space Vapor Store.

\section{DAFTAR PUSTAKA}

[1] Anggoro, D. Rancangan Sistem Informasi Koperasi Simpan Pinjam Guru dan Pegawai pada Koperasi Smk Manggala Tangerang. ISSN: 20899815. Seminar Nasional Teknologi Informasi dan Komunikasi 2015 (SENTIKA 2015). Yogyakarta. 2015.

[2] Handayani, S. Perancangan Sistem Informasi Penjualan Berbasis E-Commerce Studi Kasus Toko Kun Jakarta, p-ISSN 2087-1716 e-ISSN 2548-7779 Vol.10 No.2. 2018

[3] Handayani, S., Anofrizen, \& Jazman, M. Sistem Informasi E-Commerce Untuk Jaringan Penjualan Sepeda Motor Bekas Kabupaten Kampar, e-ISSN 2502-8995 ISSN 2460-8181. 2016.

[4] Hartono, B. Sistem Informasi Manajemen Berbasis Komputer. Jakarta: Rineka Cipta. 2013.

[5] Heizer, Render. Operation Management. Edisi8. Jakarta : SalembaEmpat. 2014.

[6] Hendrawan, A. E-Bussiness dan E-Commerce. Yogyakarta: CV.Andi Offset. 2013.

[7] Krismiaji. Sistem Informasi Akuntansi. Yogyakarta: Unit Penerbit dan Percetakan Sekolah Tinggi Ilmu Manajemen YKPN. 2015.

[8] Marhamah, Hidayatuloh, S., \& Irawan, A. Sistem ECommerce B2C Pada PT.Harapan Sentosa Nusantara Jakarta Pusat, p-ISSN 1979-0767. 2016.

[9] Mashall, B., \& Steinbart. Accounting information systems. London: London Pearson. 2015.

[10] Osterwalder, A., \& Yves, P. Business Model Generation. New Jersey: Wiley. 2012.

[11] Permana, Bayu, AD. Fungsional dari Notepad++. di https://bayudwiarta.wordpress.com/2014/10/16/fung sional-dari-notepad/ (diakses pada tanggal selasa 23 oktober 2018). 2014. 